\title{
DOCUMENTING HISTORICAL RESEARCH FOR A COLLECTION INFORMATION MODELLING. A PROPOSAL FOR A DIGITAL ASSET MANAGEMENT SYSTEM
}

\author{
E. C. Giovannini ${ }^{1}$, M. Lo Turco ${ }^{1}$, N. Mafrici ${ }^{1}{ }^{*}$ \\ ${ }^{1}$ DAD, Department of Architecture and Design, Politecnico di Torino, Italy \\ (elisabettacaterina.giovannini, massimiliano.loturco, noemi.mafrici)@polito.it
}

\section{Commission II, WG II/8}

KEY WORDS: CIDOC CRM, information modeling, museum collection, architectural model, historical research, Egyptian architecture, drawing, 3d-web platform

\begin{abstract}
:
The paper describes part of the conceptual structure produced within the still ongoing project B.A.C.K. TO T.H.E. F.U.T.U.RE. (BIM Acquisition as Cultural Key TO Transfer Heritage of ancient Egypt For many Uses To many Users REplayed). The aim of the project was to use a semantic web infrastructure to describe archival research and tracking informations related to a hidden museum collection 'expedition models of Egyptian architecture' partially stored in the depots of the Museo Egizio of Turin. The outcome will be an interactive web-presentation portal of high-resolution 3D models enriched by historical and archival set of content, from the digitization procedure applied to collection objects, to the digitization process of related data and information. The development of the collection documentation of the project illustrates how is crucial to declare the semantic description underlying narrative contents. Data about single collection objects were conceptually modelled using generalizable formulas already known by CIDOCCRM community. The description of provenance of knowledge related to the historical investigation process was modelled using CRMinf extension, exploring the possibility of making beliefs based on the available documentation and validating the results of the assumptions made during the research.
\end{abstract}

\section{INTRODUCTION}

The project took its first step since the idea of unhiding a 'hidden' series of maquette conserved at the Museo Egizio of Turin. In order to make this heritage accessible, a new improved methodology has been outlined using the tools of the information modelling for museum collections (Lo Turco, 2019). The Collection Information Modelling (CIM) (Lo Turco, Calvano, 2019) aims to improve the building model (the container) linking both data and information to the items pertaining to a collection contained in that building.

The project can be considered as a case study where documentation and investigation processes are strictly related to a visualization outcome, based on a $3 \mathrm{~d}$ platform where collection's artworks and archival research are made accessible in a digital form. (Figure 1)

In parallel with the digitization procedure applied to the museum collection objects, was also developed an information management system (Access database) intended for both storage and display of the collection's documentation.

The advent of the World Wide Web since the mid-90s had an immense impact both on the kinds of information that would be stored on museum information systems and both on who would have access to create or visualize that information.

The need to organize and re-use material generated and collected during the research, highlight the necessity to use standards and conceptual schemas.

In cultural heritage domain, the international standard ISO 21127:2006 also known as CIDOC Conceptual Reference Model (CRM) provides definitions and a formal structure for describing the implicit and explicit concepts and their relations. Nowadays the needs to show the relationships between content management both collections and digital asset management is crucial to develop systems with data that can be re-usable and implemented over future years, by people of different disciplines, with a special attention on possible narratives outcomes for education and communication purposes.

The developed relational database stores a large amount of data, metadata and paradata related to the maquette's collection and its digitized replicas in a structured and organized way: the conceptual structure is able to manage reference resources and knowledge provenance in historical research, for a born-CRM semantic data with a focus on historical attributions. In conclusion, the paper investigate the modeling of information with a specific historian approach, considering the ongoing research data and ensuring its implementation according to an interoperable process.

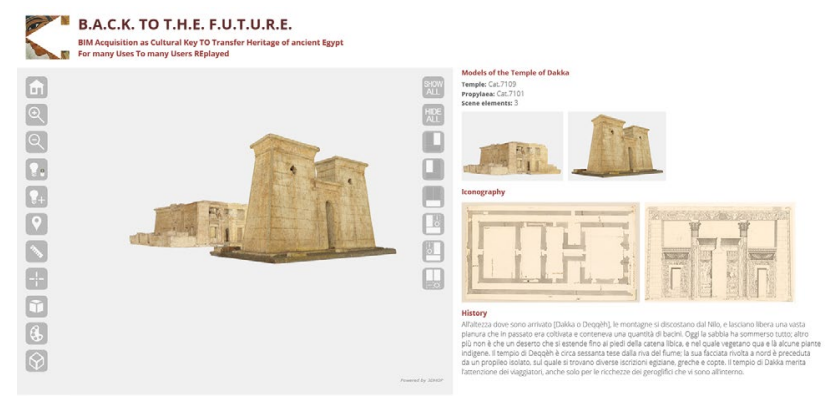

Figure 1. Web portal interface

\footnotetext{
* Although the contribution was conceived jointly, N. Mafrici is author of paragraphs 2; M. Lo Turco of paragraphs 1 and 4; E. C. Giovannini of paragraph 3
} 


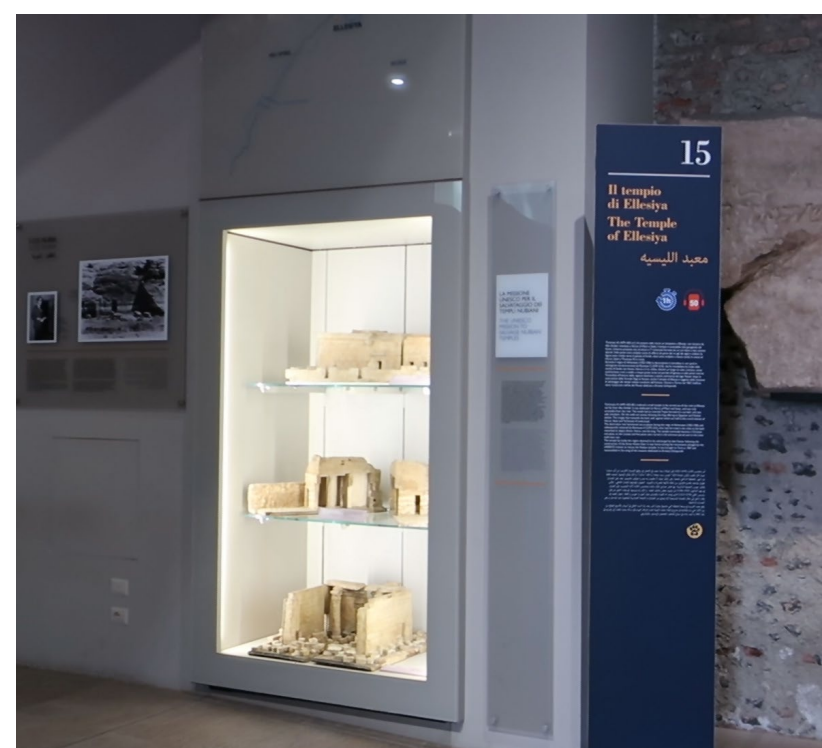

Figure 2. The architectural models displayed in the Nubian Room at the Museo Egizio of Turin

\section{THE CASE STUDY: A $19^{\mathrm{TH}}$ CENTURY COLLECTION OF ARCHITECTURAL MODELS}

The subject is a set of items consisting in fifteen wooden architectural models assembled in the early nineteenth century and representing Egyptian monuments: one obelisk and fourteen temples or parts of the same. Even if the set is considerable as a collection, it is currently disassembled and located in different settings. Two items and a part of a third are displayed in the Nubian Room of the museum (models of the temples of Beit el-Wali, Tafa South and a part of the temple of Dakka) (Figure 2); the model of the temple of Maharraqa is currently undetectable; the remaining items are stored in different depots of the museum (models of the temples of $\mathrm{Abu}$ Oda, the small temple of Abu Simbel, a part of the temple of Dakka and its propylaea, Debod and its portals, Dendur, Derr, El-Hilla, Gherf Hussein, Tafa North and the model of the obelisk of Heliopolis) (Figure 3).

The historical research aims to investigate the collection as a product of the expedition of Bernardino Drovetti in Egypt and Nubia with his team, that helped him with the excavations and the research of antiquities. At that time, the significance of these maquettes was mainly related to the architectural contents, both for who made them and for who was then in charge at the museum, and so the focus was on single objects representing single temples. Nowadays, these items together constitute a piece of a museum collection, and they represent a unique evidence of Drovetti expedition, and even more a data source. The major part of the models are composed by two parts, divided following the transversal section of the temples. The model of the temple of Dendur is composed by three parts, considering the portal in front of the temple, while the propylaea of Dakka and the portals of Debod are considered as separated items with their own catalogue number in the museum. The models, covered by plaster and painted, have been assembled with different wooden waste sticks, fixed with wax or in some cases nailed, and have suffered several restorations in the last years. Considering their inaccuracy and their bad conservation state, the importance of the models as a source is mainly related to the collection status as a whole, more than to the architectural value of each model. Within the museum, each model is a single item with its catalogue number, but their 'collection status' has been lost during their permanence in it. The historical investigation moved also with this premises, and the data have been collected with the aim of understand the value and the consistency of the series.

\subsection{Historical background}

The Museo Egizio of Turin was first opened, as 'Museo d'Antichità ed Egizio' in the current place, in 1832 (Curto, 1990). Although, its formation has to be reconducted to the 1824, when the 'Drovettiana collection' arrived to Turin. A huge part of the collection of the museum is from expeditions and discoveries of archaeologists or explorers during the first half of the 19th century: the collection of Bernardino Drovetti (from his name called 'Drovettiana') represents the core of the purchases of the museum that led to its first opening.

Within the thousand items of this collection, the models represent a unique piece made in the years contemporary to the birth of the museum, and not originally from the Ancient Egypt. The sculptor Jean Jacques Rifaud joined the group of Drovetti

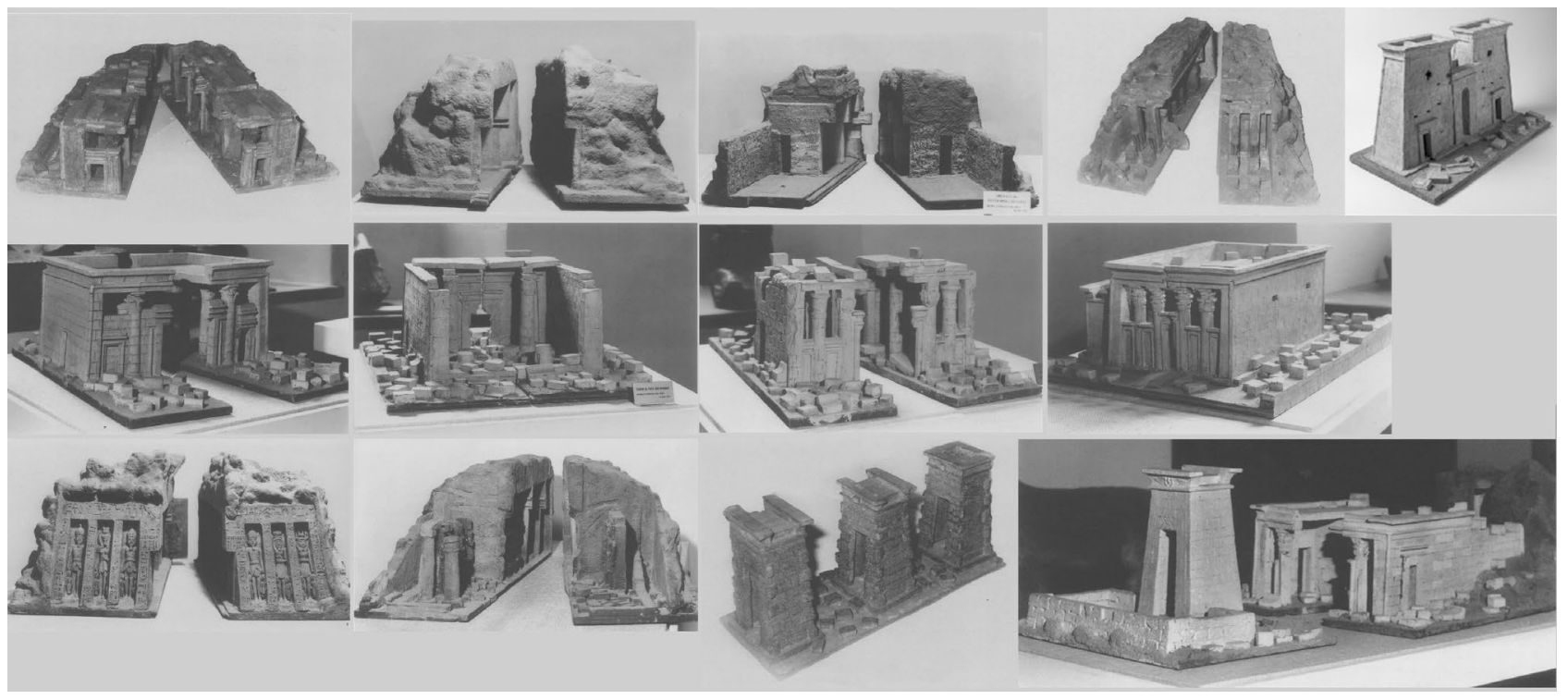

Figure 3. The collection of 'expedition models of Egyptian Architecture' 
and they made a journey until the second cataract of the river Nile through the High Egypt area and the Nubian area in 1816 and 1817. The maquettes, here denominated 'expedition models of Egyptian architecture' were distinctive items and represented an alternative, or better a support, to drawings and written reportages in the 19th century. The corpus of drawings of the sculptor Rifaud counted six thousands at the beginning (Bruwier et al., 2014) as we also can read in his manuscripted autobiography. The representations made by him and illustrating Nubian and High Egypt monuments are of different kind: plans, quoted plans, elevations, sections, perspective views, sketches. Considering the datation of the same, certainly the drawings were made during the expedition. The models, have been probably produced mainly during the 1817 , and they were probably made with an educational aim, intended as an improved mean to vehiculate in Europe a culture that was completely unknown at that time. Small versions of the monuments were surely more useful to understand the consistency of the Egyptian architecture, giving a tridimensional representation of the same. The journey they suffered to arrive in Italy had a few steps: Alessandria in Egypt - Livorno - Genoa - Turin. First, they were transported with the whole collection in a depot close to the Livorno lazareth, and remained there for five years from 1818, according to Vivoli report -'[...] la raccolta è accuratamente descritta, si parla anche dei modelli in rilievo di legno incerato degli edifici egiziani che non potevano trasportarsi, e si dice che è frutto delle fatiche di sedici anni del console francese in Alessandria Signor Drovet (sic)'- (Bresciani, 2000), to December 1823, as stated by Giulio Cordero di San Quintino, first curator of the museum and figure that was appointed, by the Savoy that bought the collection, to the check of the same collection at Livorno - Rimangono qui quindici casse contenenti modelli di antichi templi ed edifizi egiziani fatti di legno coperti di cera, non avendone trovata menzione nel catalogo io non ne ho domandata la remissione; ieri il S.r Pedemonte mi disse che avrei potuti mandarli col rimanente, ma essendo le loro case tutte aperte, e mezze rovinate, non avrei più potuto rassettarle senza trattenere il bastimento, con suo danno in questa difficile stagione.' (San Quintino letter n.2612, November 1, 1823). These previous lines are also evidence of the bad state of conservation of the collection since its manufacturing and of the consideration of the models, in terms of value and attention, already by the contemporaries.

\subsection{Historical data: inventories, catalogues and guides}

A recognition of the documentation available has been done in order to understand also the importance of the series until nowadays. After a bibliographic research, that enlightened from the literature a major interest to the paternity of the models, sources strictly linked to the museum have been analysed. Catalogues, inventories and guides have represented useful sources to reconstruct their presence within the collection first, but also to understand their consistency, their quantitative and dimensional features, and their conservation state. Accurately and analytically investigating the documentation, it is possible to understand that several errors were made from 1820 s to the latest events registering the models. Inaccuracies and approximations are the result of different inventorying criteria, that give contrasting information on the names of the temples, on their constituent items, on their catalogue numbers. The first appearance of the models could be traced back to the Orcurti catalogue of 1852. (Figure 4) This source documents the series in a chapter dedicated to 'different monuments' and it was denominated 'models of Egyptian monuments'. The order in
MONGEEsti DIVEnsI

blieata dal Burlon, Excerpta hieroglyphica, n. 14, la quale s'interpreta cosi: - Horo vivente degli uomini, re dell'alto e basso Egitto (sole offerto al - mondo), signore delle due regioni, II vivente degil vomini, figlio del sole (Sesortasen), diletto agli spiritl della reglone dil Poni sempre vivente, vita degli uomini, Horo risplendente, Dlo beneffico (sole offerto al mondo, che - ba cominclato a celebrare in giustizia le due panigirie a colul che lo fa - vivificatore per sempre. - Questo deve intendersi diretto a Phrè, a cui era dedicato il tempio. Ottre questo tempio Sesortasi I fondava il santuario di Karnak, faceva erigere le statue colossali di granito apportate in Europa da Drovetti, e le colonne monolite; tramandava la memoria delle sue spedizioni sopra la stele di Owadi-Helfa presso ai confini della Nubla, e sopra le roccie del Sinai. Due statue di questo re, usurpate da Ramesse II, formano l'ornamento del museo di Berlino (4).

40. Modello del tempio d'Ibsamboul.

Due erano gli spechi d'ibsamboul a breve distanza l'uno dall'altro, seavati nel monte occidentale. Questo modello rappresenta lo speco minore, dedicato ad Athor dalla regina Nofreari allonore di suo marito Ramses II. Delle seí gigantesche statue che ne adornano il prospetto, quattro rappresentano il re, e due la regina. Ai lati delle statue son rilevati sul medesimo monte immagini di figli e figlie reali (2).

41. Medello del tempio di Derry.

Il pronao e il santuario è seavato nel monte, e il gran cortile, o portico a pilastri, che trovasi in totale rovina, fu costrutto di pietra arenaria del monte medesimo. Fu fondato da Ramesse II, che lo dedleava a Phrè. Trovasi sulla sponda oceidentale del Nilo (3).

42. Modello del tempio di Amada.

Era dedicato a Phrè: fondato da Tutmes II, e continuato da due suoi successori, si trova sulla sponda occidentale del Nilo a breve distanza dal fume (4).

43. Modello del tempio di Essebuah.

Questo nome, che suona valle dei leoni, fu forse dato a questo monumento per le sedici grandi e belle sfingi che, partendo in doppio ordine dal fiume,

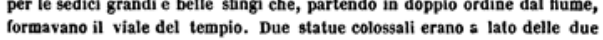
prime sffngi; e quattro più grandi, compiendo il viale, facevano fronte alla prime sfingi; e quattro piu grandi, compiendo il viale, facevano fronte alla
porta del tempio. sfingi e statue sono segnate del nome di Ramesse II, che

(1) V. Rosstuxi, tom. IIt, pag. 35, tav. M. R. n. xxvi, n. 39.

(2) V. Rossusisi, M. del culto pag. 29-36.-Cmumpoctuox, Lettres ecrites

d'Egyple et de Nubie, lettre 9.me, pag. 119

(3) V. Rosrcuxi, M. del culto, pag. 42-52. - Cresup. ibid. 145.

(4) V. Rosrulisi, M. del culto, pag. 52-53. - Chasp. ibid. p. 145.

Monum. Bgir.

Figure 4. A page from the Orcurti catalogue

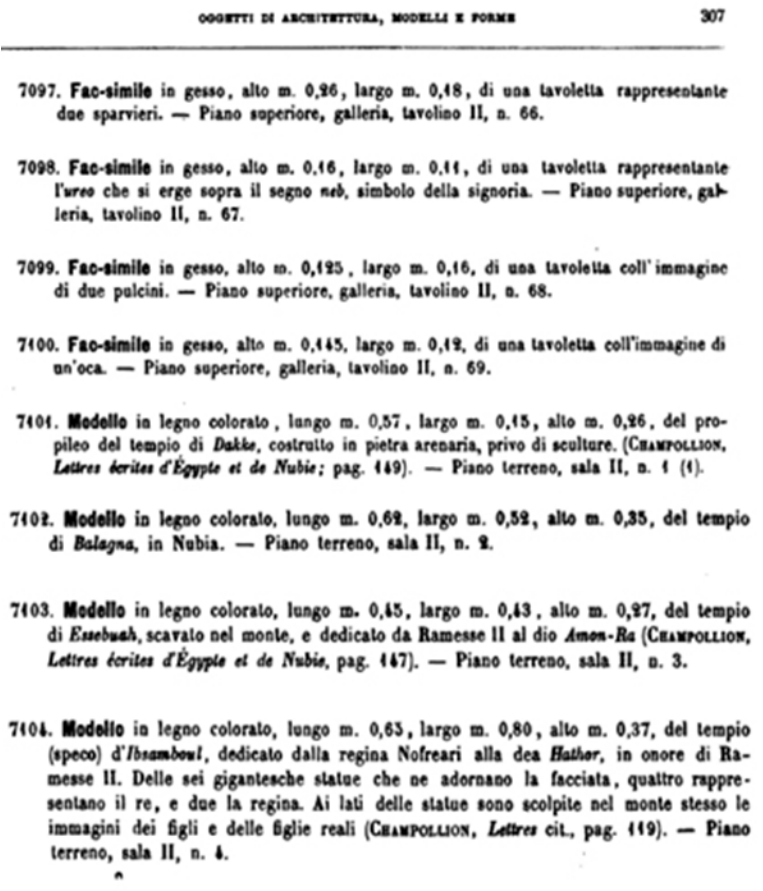

7105. Modello in legao colorato, laogo $m$. 0,50. largo m. 0,33, alto $m 0,26$, del lempio di Debodeh (Parembole), posto solla aponda sioistra del Nilo, e consecralo ad Inide e ad Amon. Ra. - Piano lerreno, sala il, n. s.

Figure 5. A page from the Fabretti, Rossi, Lanzone catalogue 
which the models of the temples were catalogued was from South to North, as a travel route, basing on the attribution given to the models by Orcurti, in certain cases wrongly referring to different temples. Following the National request of monuments inventorying, the collection of the Museo Egizio was completely inventoried in its entirely, with the Fabretti, Rossi, Lanzone catalogue in the ' 80 s of the 19th century. (Figure 5) The collection of models was integrated with the rest of the items losing its individuality and even more the order of the travel route. The consequence was that other errors of attribution to the temples have been made. In the 20th century two inventorying activities have been carried on, with the reorganisation of the museum permanent exhibition. Within the inventory of the monuments of the ground floor of the first years of the century, given to the arrival of many other items integrating the museum collection, several errors of the Fabretti catalogues have been inherited. First of all, the mistaken paternity of the models given to the archeologist Giuseppe Ferlini. The analysis of the 19th and 20th century museum guides gives a confirm to the approximation disposed to the collection: it is evident how the models lost significance within the museum collections during their permanence, not only in terms of description dedicated to them within the guides, but also in terms of display within the museum.

\subsubsection{Documenting the exception}

Looking at the literature and also at the cataloguing method, the series has always been considered as composed by Nubian temples. Within the project, new findings arise also in terms of attribution. The obelisk brought together with the other items of the series as 15th model and one of the temple, properly attributed to the temple of El-Hilla, in front of Esna, historically denominated Contra Latopolis, were not situated in the Nubian area: in al-Matariyya, Heliopolis (the obelisk) and in Haute Egypt (the temple). The placement of the monuments, to which the collection refers, contributes to the appellation 'models of Egyptian architecture'. The model of the temple of el-Hilla, has been mistaken for the temple of Kalabsha by the Orcurti catalogue, by the Fabretti, Rossi, Lanzone catalogue, and last by the catalogue of the exhibition at the Pirelli Centre in Milan of 1967. The two temples, with a façade mistakable for the similar architecture, have two different plans, with different spaces.

\section{METHODOLOGICAL APPROACH}

The methodology proposed considers the research data lifecycle that consist on three phases: creating, processing and preserving data.

According with the 'FAIR principles' data must be findable, accessible, interoperable and reusable. Then, a special attention was given not only to the collection of data phase but also to the creation of new data and information discovered during the historical research.

Taking into account the collected documentation, the database created for the project, manages information about fifteen Models of Egyptian architecture and is able to manage historical, archival and iconographical data related to the objects to which they refers.

The available documentation (inventory cards, photos, drawings, catalogues, guides etc..) is characterized by a strong interpretative value that must be declared during the publishing phase taking into account the necessity to describe provenance and to use international standards.

The research core was, in fact, to define a methodology able to support the documentation of archival and historical research, focusing the attention on data extrapolated by different documents. The documentation was deconstruct in its parts and each data or implicit knowledge information carried on by each source was collected in the central management system.

\subsection{Creating data from collection and analysis}

Starting from the assumption that data must be collected and stored in a declared way, the part of the project described, consist on the documentation of data of two catalogues and twenty planches.

Digitizing data from catalogues means that could be possible individuate similar kind of information but not always the same ones.

In this case catalogues, contains numerical identifiers, appellation of the object, and indication about the place where the object is stored or exhibited in the museum, its measurements, and a short description of the temple depicted by the object. Data available from catalogues were stored in the 'catalogue transcript' that is used as a table to store descriptions of temple depicted by the object.and other data ; 'models_appellations' contains a list of appellations assigned to objects, 'ID_mod_identifiers' contains a list of IDs that correspond to the inventory numbers proposed by catalogues. From both documents was possible to obtain other informations related to the exhibition room of the Museo Egizio and the place appellation contained in the description of the temple: all referenced place names were stored in the 'place_appellations' table. (Figure 6)

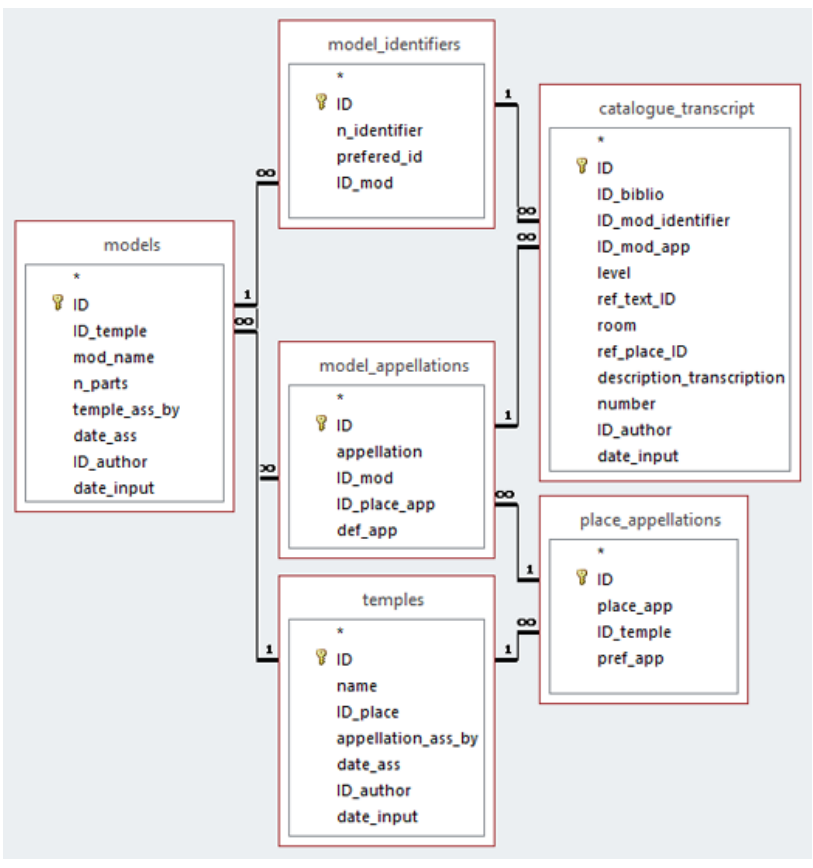

Figure 6. database relationship structure for catalogue transcripts and its connected tables

The tables are connected to the museum collection object by the 'models_appellations' sheet that contain the reference id of the 'ID_model' assigned by the project.

The analysis of data extrapolated by the documentation showed how, over the years, the name of the temple depicted by the object, changed. This could be a considerable issue when there is the necessity to identify a correct temple in a correct place and find a way to uniquely name the object. Then was necessary, not only to list all places appellation but also to verify the appellation attribution and its references. Talking 


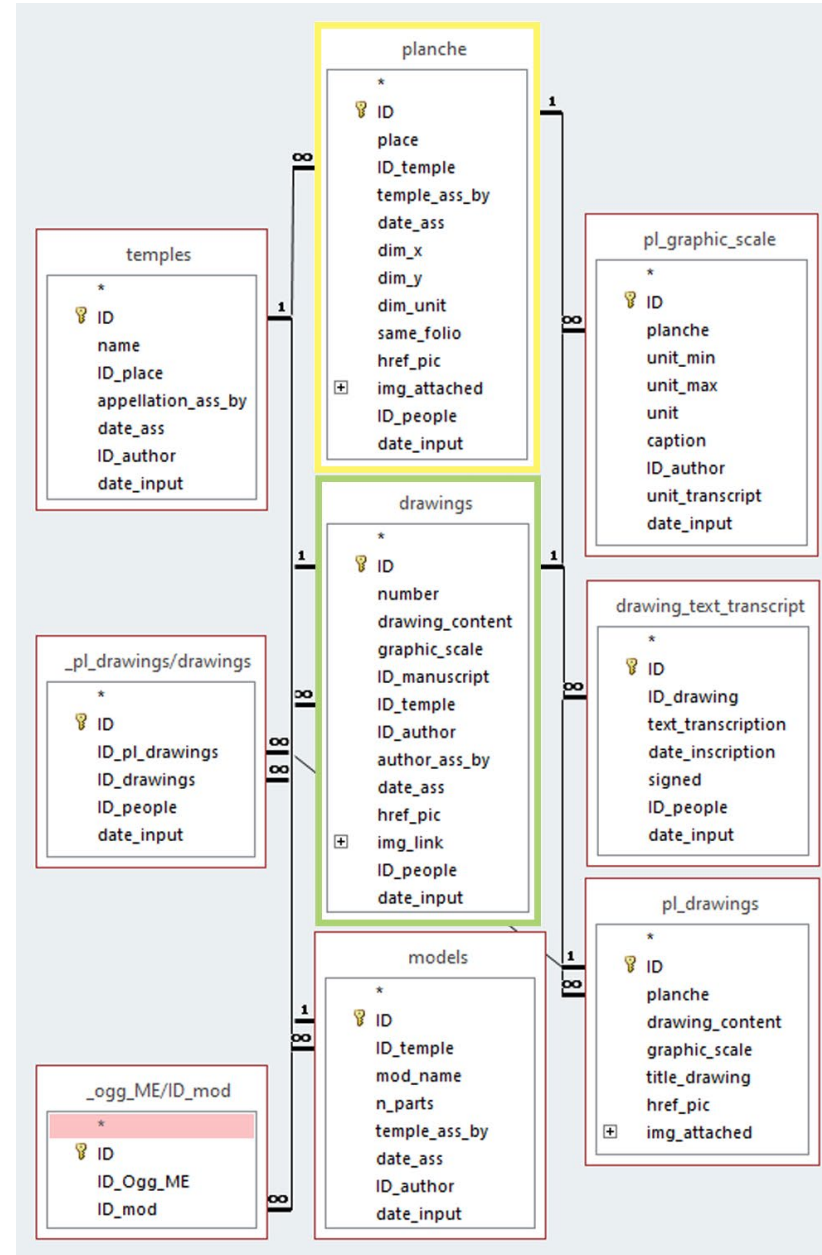

Figure 7. database relationship structure for planches and drawings.

about historical places the project takes into account also ancient names. The temple appellation assignment did not take into account the name of the deity to whom the temple itself was dedicated, but only the name of the place, as indicated in the catalogues consulted.

To do that, also an iconography contemporary at the date of possible construction of the objects was identified and the current 'modern name' was assigned to the object.

The iconography chosen was a list of planches recently published in 'La Description de l'Egypte de Jean-Jacques Rifaud (1813-1826)'. These planches were part of the graphic apparatus of the volume 'Voyage en Égypte, en Nubie, et Lieux Circonvoisins, depuis 1805 jusqu'en 1827" edited by J. J. Rifaud.

Planches consist of a series of drawings with a title and a reference planche number: their titles are listed in a index written in old french language. Planches available are in different format and made by different printing company and lithographers, but all lithographies collected are made following original drawings of J. J. Rifaud. Sometimes it is possible to have planches with only one architectural representation and sometimes with a composition of more drawings representing temples: perspectives, plans, sections, details or hieroglyphics transcription. Plans are generally accompanied by graphic scale.

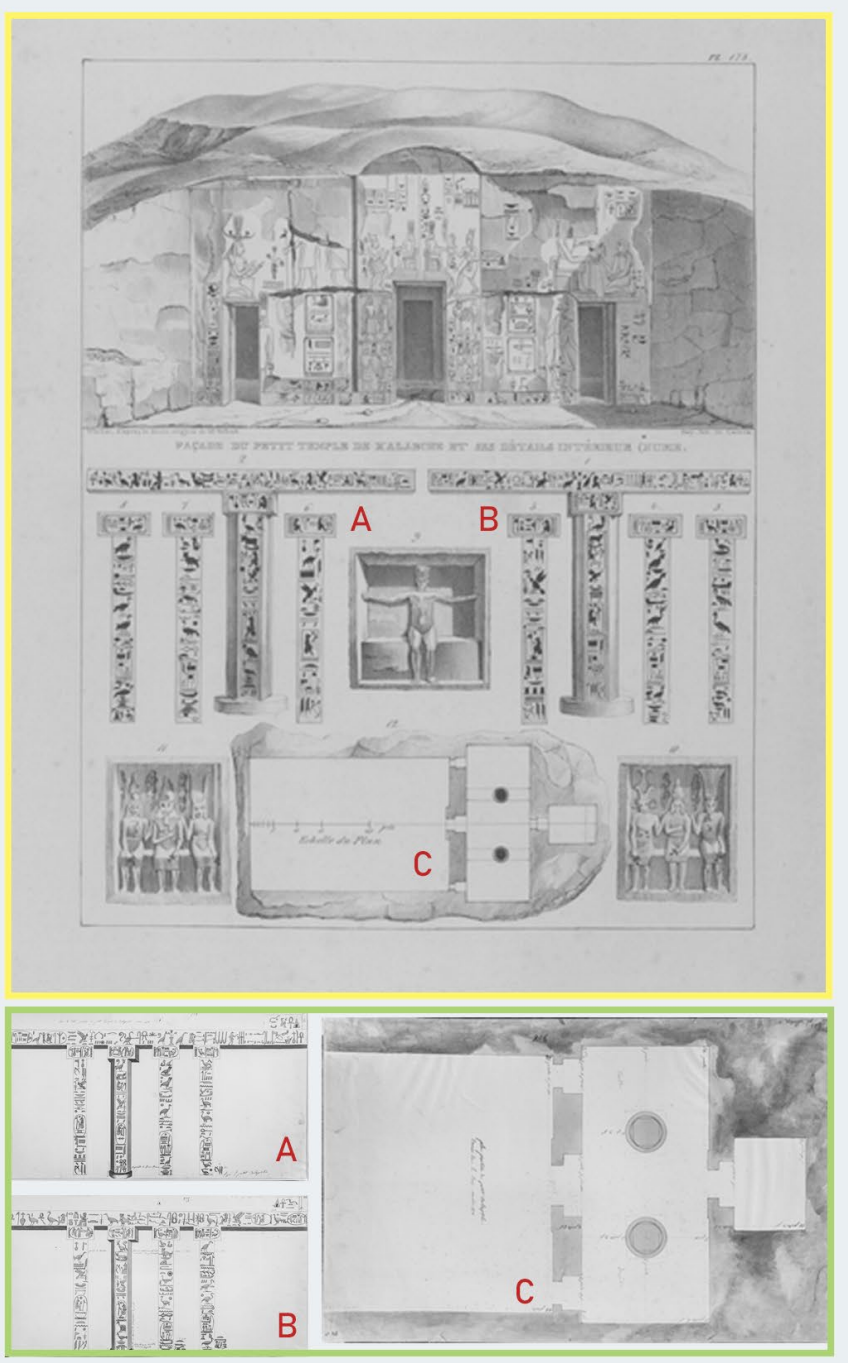

Then the historical research, to enrich iconographic references, collected also original drawings. Then a dedicated set of the database tables were made to connect original drawings and planches. (Figure 7)

\subsection{Data modeling and provenance of knowledge for the model of the Temple of el-hilla}

The database stores not only the collection of previous documentation but also new knowledge produced by the acquisition phase, related to the digitization process, historical research phase and knowledge documentation for communication purposes. To describe the modelling information process the paper will focus on the description of the model of a temple in the small city of el-Hilla, originally called Contra Latopolis, the only one representing a temple outside the Nubian area. The analysis of the model enlightens some of the incongruities related to its denomination (appellation provenance) and to the attribution of the subject of the model itself (inferences and beliefs). This paragraph describes the procedure used by historian to identifying the temple associated iconography, based on observation of morphological and iconographical similarities (Fig. 8) trying to clarify relevant aspects of the maquette consistence. 


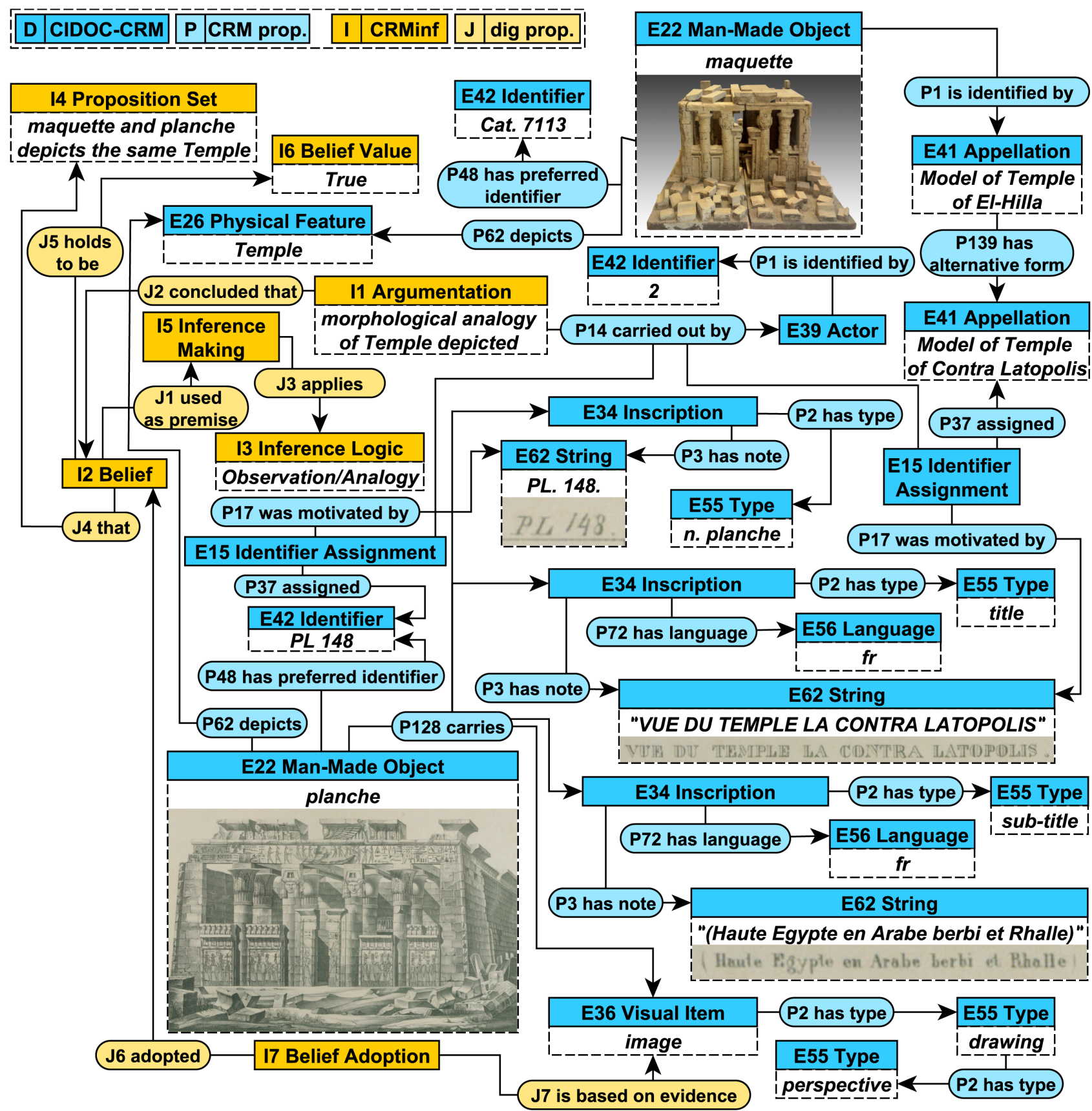

Figure 8. Data modelling of the "maquette and planche association" based on archival documentation

After the collection phase and the analysis of documentation available one of the first challenge was the assignment of the name of a temple to each object, then the necessity to find a set of iconography available for all objects, to have the same kind of content to show on the web portal dedicated to single objects. Even if some of them were clearly recognized, because famous and well represented and described not only by historical sources but also by web resources. For some of them, because are nowadays lost, it was not easy to identified the real name. This is the case of the model of the Temple of El-Hilla.

The Temple ID, according to the Museo Egizio maintain the inventory number Cat. 7113 and a description 'Modellino del tempio El-Hilla (Contralatopolis)' then the Figure 8 explains how is possible, using CIDOC-CRM and its extensions, to conceptual modelling "maquette and planche association" based on archival documentation. The schema shows the entities of the ontology and how data from the database of Museo Egizio can be mapped. Planches and their implicit information were divided and all text and images were mapped following CRM classes and properties. Finally, for integrating metadata about argumentation and inference making, was used the CRMinf extension.

\section{CONCLUSIONS}

The project aim to define a new methodology in which the Information Modeling tools can be used for unconventional purposes, to realize $3 \mathrm{D}$ web platform connected to a databases of small objects that contain digitization data and historical and archival information. Tracing the relationships between objects and documents, through the use of a central information management system should be a recommendable practice for the re-use of information. 


\section{ACKNOWLEDGEMENTS}

The research is a part of the pilot initiative "Create a network around your research idea" and is funded within the framework of the collaboration between Politecnico di Torino and Compagnia di San Paolo. The research was developed in collaboration with the Museum of Egyptian Antiquities (Museo Egizio) of Turin and the University of Salamanca.

\section{REFERENCES}

Bresciani, E., 2000. La Piramide e la torre: due secoli di archeologia egiziana. Pacini, Pisa, 20

Bruseker, G., Carboni, N., \& Anais, G. (2017). Cultural

Heritage Data Management: The Role of Formal Ontology and CIDOC CRM. https://doi.org/10.1007/978-3-319-65370-9

Bruwier, M.-C., Claes, W., Quertinmont, A., 2014. La Description del l'Egypte de Jean-Jacques Rifaud. Editions Safran, Bruxelles.

Curto, S., 1990. Storia del Museo Egizio di Torino. Centro Studi Piemontesi, Torino. (first ed. 1976), 32

FORTH-ICS. (2012). 3M - Mapping Memory Manager. Retrieved from http://139.91.183.3/3M/

Frommel, S., Tassin, R. (eds.), 2015. Le maquettes d'architecture : fonction et évolution d'un instrument de conception et de réalisation. ePicard, Paris; Campisano editore., Roma.

Fabretti, R. V., Rossi, F., Lanzone, A., 1888. Regio Museo di Torino ordinato e descritto da A. Fabretti, F. Rossi e R.V. Lanzone. In 'Ministero della Pubblica Istruzione (ed.), Catalogo Generale dei Musei di Antichità e degli Oggetti d'Arte raccolti nelle Gallerie e Biblioteche del Regno'. Direzione Generale delle Antichità e Belle Arti, Rome.

Giovannini, E.C., Mafrici, N. (in course of publication). Digitalizing Data: from the historical research to data modelling for a (digital) collection documentation. In Lo Turco, M. (ed.), 'Documentation \& Digital - vol.2. Digital strategies for Cultural Heritage', Pavia University Press, Pavia.

Incontro con una civiltà millenaria: mostra dedicata all'Egitto antico e contemporaneo. Centro culturale Pirelli, Milano, exhibition catalogue, 10-25 marzo 1967.

Lo Turco, M., 2019. The digitization of museum collections for the research, management and enhancement of Cultural Heritage. In Parrinello S. (ed.) 'Documentation \& Digital'. Pavia University Press, Pavia, 91-103.

Lo Turco, M., Calvano, M., 2019. Digital Museums, Digitized Museums. A. Luigini (ed.). In Luigini, A. EARTH 2018. AISC 919, Springer Nature Switzerland. pp.387-398.

Orcurti, P.C., 1852. Catalogo illustrato dei monumenti egizii del R. Museo di Torino. Tipografia nazionale di G. Biancardi e compagni, Turin.
Scolari, M., 2005. L'idea di modello. In Gulinello f. (ed.), 'Modelli di Architettura', Il Vicolo, Bologna, 24-55.

Thomas, S., 2012. Displaying Egypt: Archaeology, Spectacle, and the Museum in the Early Nineteenth Century. Journal of Literature and Science, 5, 1, 6-22. 